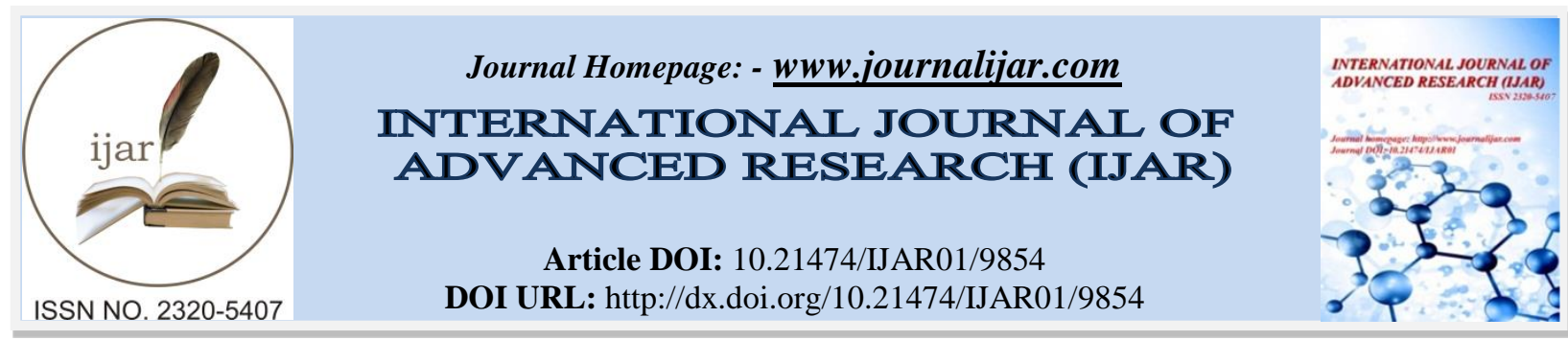

RESEARCH ARTICLE

\title{
PHOSPHORUS MANAGEMENT THROUGH THE APPLICATION OF RECYCLED FERTILIZERS IN ECOLOGICAL WHEAT PRODUCTION.
}

\author{
Emina Mešinović, Besim Salkić,Ahmed Salkić and Adela Mujić. \\ Faculty of Technology, University of Tuzla.
}

\section{Manuscript Info}

\section{Manuscript History}

Received: 08 August 2019

Final Accepted: 10 September 2019

Published: October 2019

\section{Key words:-}

phosphorus management, recycled phosphorus fertilizers, developmental stages wheat.

\begin{abstract}
With the growth of the population, agricultural production has intensified, and in order to sustain itself, sustainable provision of soil with phosphorus, which is in an accessible form for plants, is crucial. For this reason, it is necessary to think of ways to "recover" phosphorus through the production of recycled phosphorus fertilizers.

The experimental part of this paper covers tests to determine the following parameters: soil nutrient content, wheat development stage, plant height, water consumption, chlorophyll content, and yield (straw and grain).

The aim of the study is to determine, with all necessary measurements and analyzes, whether and to what extent there are differences in the use of manure (Farmyard Manure), P-Rock Morocco, Dolophos, Berliner Pflanze on the growth, development and yield of wheat in relation to the part of the experiment that does not contain none of the fertilizers listed.

The use of recycled fertilizers in organic wheat production can increase sustainability, given the fact that they are slow release nutrients, and their application helps to close the cycle of phosphorus in nature.
\end{abstract}

Copy Right, IJAR, 2019,. All rights reserved.

\section{Introduction:-}

Phosphorus is an essential resource for plants, animals and humans, but crude phosphates are non-renewable mineral resources that are excavated in only a few countries. In order to maintain soil fertility, certain agro-technical measures must be applied, and fertilization is one of them. Unlike in conventional production where it is possible to directly feed the plant, in organic production nutrients are primarily introduced into the soil, therefore fertile soils form the basis of a balanced plant nutrition (Bioland, 2013).

With global population growth, agricultural production has intensified, and thus the number of producers in the organic production system has increased. As a result, significant amounts of nutrients are removed from the farm as waste and irreversibly lost. Landfills of both biogenic and other liquid or solid wastes are increasing. This led to the eutrophication of water surfaces and also to the inability to close the cycle of phosphorus circulation in nature. In recent years, emphasis has been placed on various studies through EU projects, which are based on the evaluation of innovative and available technologies for the "recovery" of phosphorus from various sources. Complementing market analysis, a brief policy overview and guidance for policymakers and end-users demonstrates acceptable phosphorus recovery and recycling options given regional (structural and legislative) conditions. Technology is not a solution in itself, it must fit into entire value chains or even value cycles, and adapt to a sustainable and well- 
balanced circular economy (Nättorp and Remmen, 2017). The methodology has been practice oriented to present a broad picture of all relevant aspects of the technologies and options for the sustainable use of phosphorus today, enabling the transition to a circular economy without interruption of the phosphorus cycle. In order to maintain the intensity of agricultural production, it is essential that the soil is provided with nutrients that are accessible to plants. In keeping with these issues, the experts came up with the idea to "recover" phosphorus through the production of recycled organic phosphorus fertilizers that will meet environmental goals (this means reducing $\mathrm{N}$ and $\mathrm{P}$ losses through surface water as well as reducing the consumption of non-renewable P sources) and as such that they can be used in organic / organic production. Phosphorus is one of the key factors in agricultural production.

In addition to legumes, which have a high proportion of typical crop rotation in organic farming systems, there is also the possibility of using recycled phosphorus fertilizers, including those with higher and lower phosphorus bioavailability (Wollmann et al., 2018). One of the good and essential features of recycled organic fertilizers is that they release nutrients slowly, which is good for sustainable phosphorus management. Its "recovery" itself would be a step in closing the cycle of nutrient cycling and would contribute to sustainable management.

The supply of phosphorus to a particular soil type is influenced by: the mineral composition and physical properties of the soil, the amount of clay, $\mathrm{pH}$ and temperature, and to a large extent contributes to the anthropogenic influence (Feller, 2016).

In the European Union (EU), 116 tonnes of waste and sludge are produced annually, providing more than 300,000 tonnes of phosphorus annually (Gendebien, 2010). The direct application of bio-waste and sludge in organic / organic production in the EU is prohibited, given the risk of contamination with harmful substances (Commission Regulation EC 2008). Organic farming, on the other hand, allows the efficient use and recycling of nutrients. Phosphorus recovery technologies are extremely sophisticated and are able to overcome any limitations in this segment. In addition to recycling, efficient use of phosphorus implies good soil selection as well as the choice of phosphorous fertilizer through a nutrient mobilization approach, that is, the transition of inaccessible to accessible (available) nutrient forms. The low reaction, ie $\mathrm{pH}$, has an effect on the availability and mobility of phosphates in the soil. The availability of phosphorus also depends significantly on the soil moisture condition and the rate of phosphoric acid recovery in the aqueous phase of the soil. Also, soil microorganisms have an effect on the accessibility of phosphorus to plants through the process of mineralization and on the stimulation of root growth in order to increase the availability of phosphorus (Feller, 2016) The legal framework for the fertilization and use of fertilizers in organic farming is laid down in EC Regulation on Organic Farming No. 834/2007 and European Commission Implementing Provisions no. 889/2008.

In addition to the aforementioned EC Regulation, some EU Member States also adopt additional Regulations on the labeling of fertilizer preparations that can be used in organic farming, however, such Regulations are of national relevance only and do not apply to other EU Member States and countries transition. Phosphorus recovery is undoubtedly at the cutting edge of technological development. There are several thermal, chemical and biological technologies that are on the cusp of achieving economic competitiveness by replacing other, unsustainable pathways. Ultimately, bio-waste (eg food waste) can be economically recycled since it is available in a very concentrated form. These phosphorus recycling technologies should be supported by appropriate political or legislative action (Ohtake and Tsuneda, 2019). Recycled fertilizer is easy to produce, clean, easy to handle because it is concentrated, granular, non-sludge and odorless. In addition to field crops, it can also be used for potted plants, fruit trees and ornamental plants (Westerman, 2009). The effect of R-fertilizer depends on the soil type due to differences in solubility and sorption properties of the soil. It is most effective in soils of moderate or low pH, but its efficiency is limited in soils with low fertility and high $\mathrm{pH}$. The solubility of the fertilizer improves under acidic conditions, increasing efficiency. Acidic conditions result in increased $\mathrm{P}$ adsorption into the soil and hence its dissolution and availability. The solubility is minimal $(0.040 \mathrm{mM})$ in the $\mathrm{pH}$ range of $8.2-8.8$ (Le Corre et al., 2009), which can increase to $1-10 \mathrm{mM}$ at $\mathrm{pH}<5$. In acidic and neutral soil solution, the solubility remains in the range of $65-100 \%$, which is similar to that of $\mathrm{P}$ fertilizers used in conventional production (triple superphosphate) (Cabeza et al., 2011). This implies that under acidic and neutral conditions, the fertilizer would have a similar fertilizing effect as the synthetic fertilizer (Massey et al. 2007).

\section{Materials And Methods:-}

Fertilization significantly affects the stability of yields and soil fertility, which are very closely related, as higher fertility implies greater availability of nutrients and greater ability of the soil to offset to some extent adverse 
seasonal impacts (eg drought) and the unfavorable impact of insufficient or excess nutrition (soil elasticity) and thus contributes to the stability of yield (Loncaric and Karalic, 2015). If the availability of nutrients before fertilization is insufficient and therefore a limiting factor of production, fertilization will increase the yield. However, if nutrient availability was already optimal, fertilizing increased availability would certainly have a negative effect on quality, and ultimately would result in lower yields due to a lower harvest index (eg higher proportion of straw in the above ground mass of wheat), laying of cereals, more intense attack of pathogens. , but also because of the possible toxic effect of nutrient over-availability (Loncaric and Karalic, 2015). Analyzes and measurements for the experimental part of this work were performed at a field experimental station in Berge, Nauen belonging to the Institute for Agricultural and Urban Ecological Projects affiliated with the Humboldt University (Institut für Agrar- und Stadtökologische Projekte an der Humboldt-Universität) in Berlin.

IASP is an interdisciplinary research institution that identifies, designs and implements innovative projects in science, research and development. Experiments with crops such as cereals, corn, potatoes, rapeseed and legumes are carried out on about 13 ha of arable land. Research deals with genotypes, organic and mineral fertilizers, biogas digesters, irrigation and crop protection. In addition to the open fields, there is also a semi-open (grid-protected side) greenhouse within the station, where a trial was set up for this research under a project called (Nurec4org-Nutrient recyclates for organic farming) implemented by IASP and funded by Deutsche Bundesstiftung Umwelt (DBU), and within this scope tests are carried out to determine the following parameters:

1. Nutrient content of soil

2. Wheat development stage

3. Plant height

4. Water consumption

5. Chlorophyll content

6. Yield (straw and grain)

\section{Treatments}

1. Controlled - without fertilizer application (1)

2. Farmyard Manure (2)

3. P - Rock Morocco (5)

4. Dolophos (8)

5. Berliner Pflanze (8)

Given that 5 of the total of 12 treatments that were applied and whose impact was monitored on wheat were selected for this work, they are indicated by different numbers that are not chronologically ordered. The variants are numbered 1,2,5,8 and 9, respectively, and the results will be shown under these numbers, while the vessel numbers are specially marked.

For the experiment, Mitscherlich pots whose dimensions in the table were marked under size I were used for the experiment, with no plant holders or lower pan holders being used, as the pots were fixed on tables. The soil was taken from two different sites, which have been in the organic / organic production system for years After collection, soil was sifted in order to remove mechanical and biological impurities. The soil was mixed well with inert quartz sand (previously washed and dried at $105^{\circ} \mathrm{C}$. The soil and sand were mixed to achieve a good water-air regime. In addition, the soil and sand were mixed in a 1: 1 ratio to The total phosphorus content was reduced 40 samples, 4 repetitions were selected for each treatment with heavy and light soil, $6 \mathrm{~kg}$ of soil and $1 \mathrm{~g}$ of fertilizer were prepared for each vessel. The top is left scattered and a seed pattern is planted over the flattened surface and the seeds are sown at a depth of $2 \mathrm{~cm}$. a useful plant as a nitrogen fixer, the goal was to keep the soil rich in nitrogen after growing it. In the spring of the 2018 season, $3 \mathrm{~g}$ of $\mathrm{K} 2 \mathrm{O}$ was added to each pot, and in April, sowing of the main crop, wheat (Triticum aestivum), of the variety SW Kadrilj, was started. The seeds of this variety are certified as organic. Each grain was seeded with 15 grains of wheat, and after sprouting, the number was reduced to 10. The seeds of this variety were certified as organic. Each grain was sown with 15 grains of wheat, and after sprouting, the number was reduced to 10. For the duration of the experiment, the layout of the vessels changed due to the same brightness. The stages of growth and development are determined by the $\mathrm{BBCH}$ scale.

\begin{tabular}{|l|l|}
\hline Stages & Description \\
\hline 0 & Germination / sprout / bud development \\
\hline
\end{tabular}




\begin{tabular}{|l|l|}
\hline 1 & Leaf development (main shoot) \\
\hline 2 & Lateral shoot formation / plowing \\
\hline 3 & Article extension or rosette development / tree (main tree) \\
\hline 4 & Development of harvesting parts of plants or vegetative organs for reproduction / booting (main tree) \\
\hline 5 & Occurrence of flower parts (main tree) / grading \\
\hline 6 & Flowering (main tree) \\
\hline 7 & Fetal development \\
\hline 8 & The ripening or ripening of fruits and seeds \\
\hline 9 & Aging, beginning to stand still \\
\hline
\end{tabular}

Plant growth was measured by a wooden meter from the base to the end point at the top of the plant, with plants measuring approximately the same height being selected in one measuring vessel. In this way, the difference in height of the plants in relation to the treatment applied was monitored. Plant height was measured once a week between $04.06-18.06 .2018$ and once every two weeks from 18.06 - 01.07.2018. years. Growth measurement was performed a total of 4 times.

Water consumption was measured in such a way that each container was weighed on an industrial scale for Combics 3 static control, and on the basis of the differences between the initial and the weight at a given moment of weighing, water was added to the vessels $/ 1 \mathrm{gr}=1 \mathrm{ml} /$. Initially, the plants were irrigated every $4-5$ days and then every other day.

Chlorophyll content, that is, nitrogen content, was measured using an $\mathrm{N}$-tester.

Ordinary scissors were used for the harvest. It was made by cutting off the classics and collecting them in specially labeled plastic packaging with the specified sample number. Harvesting was done in such a way that they were cut to the surface of the soil in the pot.

After harvest, the samples were dried at $75^{\circ} \mathrm{C}$ for $24 \mathrm{~h}$.

Grains were manually separated from each class.

For grain counting, a Contador counter was used, which is suitable for grain sizes $0.3 \mathrm{~mm}-15 \mathrm{~mm}$. After counting, on a precision digital laboratory scale (Kern PCB), the weight of the grain from each treatment vessel is weighed. After each weighing, the mass was entered in the table, which was used to compare the yield with the fertilizers used. The determination of phosphorus content in soil was performed by the DL method.

\section{Results And Discussion:-}

Wheat development stage full ticking is indicated by number 25 . According to the $\mathrm{BBCH}$ scale, it was most pronounced in plants that received treatment under number 1 . In a slightly smaller percentage compared to this treatment, it was in plants where treatment was used 9. In plants where they were used treatments 8 and 9 showed no noticeable differences in the formation of shoots from the subterranean roots of the tree, while wheat in the bins at treatment 1 had a much weaker bunch. Elongation of the stem cells was first observed in most vessels at treatment 9 , then treatment numbered 2, 5, 8 and at the latest in samples where treatment numbered 1 . In plants where treatment 2 and 9 was used, this phase lasted much longer. . In class 51-55, treatment class 1 showed lower class differentiation, while in phase 59 (end of classing) it could be seen that the class remained shorter and the leaves were much narrower. Differences were also noticeable on leaf color. The darkest leaves were where treatment 2 was applied, which could be related to the nutrient content, since there was also a considerable amount of nitrogen in the manure, and the lightest in samples under treatment 1, where no fertilizer was applied. Stage 61, start of flowering, where pollen bags were first observed in samples using treatment 9 , then in samples using treatment 5 , but in a much smaller percentage, whereas in samples where other treatments were used, flowering was delayed. Phase 65, full bloom, 06/15/2018 was in almost all vessels where treatment 9 was used, while in samples with treatment 5, about $70 \%$ of the clumps that completed flowering were seen, less than in treatments 8 and 1 , and the lowest in samples under treatment 2. The formation and filling of the grain was first observed in treatments 9 , then 5 and 1 (taking into account all 4 stages: milky, doughy, waxy and full ripening). In treatment 8 , these stages occurred a little later, and 
in the samples using treman, the grains did not fully mature and some of the clusters were still green. The harvest was done on 12/07/2018. years in all vessels.

\section{Plant height / growth}

Table 1:-Average growth of wheat plants by treatments in the period 04.06 to 01.07 .2018 . year (easy soil)

\begin{tabular}{|l|l|l|l|l|l|}
\hline Treatment (light soil) & Label & \multicolumn{4}{l|}{ Measurement date } \\
\hline & & 04.06 .2018 & 11.06 .2018 & 18.06 .2018 & 01.07 .2018 \\
\cline { 3 - 6 } & & Increase $(\mathrm{cm})$ & Increase $(\mathrm{cm})$ & Increase $(\mathrm{cm})$ & Increase $(\mathrm{cm})$ \\
\hline Control & 1 & 39 & 43 & 47 & 51.75 \\
\hline Manure & 2 & 45.5 & 51.25 & 52.75 & 56.75 \\
\hline P-Rock Marroko & 5 & 40 & 44.2 & 48 & 51.75 \\
\hline Dolophos & 8 & 40.35 & 44.5 & 48.5 & 52.25 \\
\hline Berliner Pflanze & 9 & 45.75 & 50 & 53.25 & 59.25 \\
\hline
\end{tabular}

According to the results shown in Table 1, it is evident that on the first measurement 04.06.2018. The smallest increase was observed in controls, slightly more in P-Rock Morocco and in the treatment with Dolophos, while a much larger increase was observed in the treatment with Berliner Pflanze.

Table 2:-Average growth of wheat plants by treatments in the period 04.06 to 01.07.2018. years (heavy soil)

\begin{tabular}{|l|l|l|l|l|l|}
\hline Treatment (heavy soil) & Label & \multicolumn{4}{l|}{ Measurement date } \\
\hline & & 04.06 .2018 & 11.06 .2018 & 18.06 .2018 & 01.07 .2018 \\
\cline { 3 - 6 } & & Increase $(\mathrm{cm})$ & Increase $(\mathrm{cm})$ & Increase $(\mathrm{cm})$ & Increase $(\mathrm{cm})$ \\
\hline Control & 1 & 44.25 & 48.25 & 51 & 54 \\
\hline Manure & 2 & 43.5 & 46.5 & 49.8 & 54.5 \\
\hline P-Rock Marroko & 5 & 42.25 & 44.5 & 48.6 & 55.5 \\
\hline Dolophos & 8 & 44.25 & 47 & 51.5 & 55.25 \\
\hline Berliner Pflanze & 9 & 47.25 & 50 & 53 & 56 \\
\hline
\end{tabular}

By comparing the samples in light and heavy soil (sandy and clayey) it can be seen that during the first measurement 04.06.2018. In 2007, a larger increase was observed in samples with heavier soil. The increase during the first measurement was, on average, $2.18 \mathrm{~cm}$ higher than the samples in light soil. Last measured 01.07.2018. year, a larger increase was observed in plants that were in light soil with manure and Berliner Pflanze treatments. However, in plants under control treatments, P-Rock Marroko and Dolophos, a greater increase was observed in heavier soil.

\section{Average water consumption}

Table 3:-

\begin{tabular}{|l|l|l|l|l|l|l|l|}
\hline $\begin{array}{l}\text { Treatment } \\
\text { (light soil) }\end{array}$ & Target value & Weight & $\begin{array}{l}\text { H2O } \\
\text { consumption } \\
(\mathrm{ml})\end{array}$ & $\begin{array}{l}\text { Treatment } \\
\text { (heavy soil) }\end{array}$ & Targe value & Weight & $\begin{array}{l}\text { H2O } \\
\text { consumption } \\
\text { (ml) }\end{array}$ \\
\hline 1 & 8612 & 8030 & 582 & 1 & 8560 & $790 \mathrm{~h} 0$ & 660 \\
\hline 2 & 9255 & 8300 & 955 & 2 & 9291 & 8270 & 1021 \\
\hline 5 & 8636 & 8080 & 556 & 5 & 8616 & 8052 & 564 \\
\hline 8 & 8724 & 8330 & 394 & 8 & 8598 & 7568 & 1030 \\
\hline 9 & 8598 & 8090 & 508 & 9 & 8880 & 7620 & 1260 \\
\hline 1 & 8617 & 8020 & 597 & 1 & 8630 & 8060 & 570 \\
\hline 2 & 8656 & 7820 & 836 & 2 & 9210 & 8190 & 1020 \\
\hline 5 & 8628 & 8200 & 423 & 5 & 8664 & 8060 & 604 \\
\hline 8 & 8638 & 8080 & 558 & 8 & 8849 & 7965 & 884 \\
\hline 9 & 8596 & 8180 & 416 & 9 & 8816 & 8240 & 576 \\
\hline 1 & 8613 & 8312 & 301 & 1 & 8570 & 8035 & 535 \\
\hline 2 & 9225 & 8394 & 813 & 2 & 8821 & 8120 & 701 \\
\hline 5 & 8746 & 8500 & 246 & 5 & 8622 & 8011 & 611 \\
\hline 8 & 8609 & 8360 & 249 & 8 & 8624 & 8155 & 469 \\
\hline
\end{tabular}




\begin{tabular}{|l|l|l|l|l|l|l|l|}
\hline 9 & 8596 & 8125 & 471 & 9 & 8781 & 8130 & 651 \\
\hline 1 & 8613 & 8180 & 433 & 1 & 8613 & 8130 & 483 \\
\hline 2 & 8637 & 8320 & 317 & 2 & 9008 & 8200 & 808 \\
\hline 5 & 8680 & 8100 & 580 & 5 & 8750 & 8305 & 445 \\
\hline 8 & 8596 & 8030 & 566 & 8 & 8630 & 8120 & 510 \\
\hline 9 & 9231 & 8100 & 1131 & 9 & 8856 & 7600 & 1256 \\
\hline
\end{tabular}

Samples under treatments 2 and 9 (manure and Berliner Pflanze) had the highest water requirements for light as well as heavier soil. This is a result of the larger number of plants that developed during the budding phase compared to the plants under other treatments, which directly reflected on water needs.

\section{Chlorophyll content}

Table 4:-Average leaf chlorophyll content (light soil)

\begin{tabular}{|c|c|c|c|c|c|c|}
\hline Treatment (light soil) & Label & \multicolumn{5}{|c|}{ Measurement date } \\
\hline & & 28.05 .2018 & 04.06 .2018 & 07.06 .2018 & 11.06 .2018 & 18.06.2018 \\
\hline Control & 1 & 419.5 & 327.75 & 399.75 & 414.5 & 388.75 \\
\hline Manure & 2 & 603.75 & 500.75 & 601.5 & 611 & 549 \\
\hline P-Rock Marroko & 5 & 399 & 318.5 & 397.25 & 430.25 & 377.75 \\
\hline Dolophos & 8 & 451.25 & 352 & 399.25 & 490 & 402 \\
\hline Berliner Pflanze & 9 & 582.25 & 390.25 & 606.75 & 547 & 489.5 \\
\hline
\end{tabular}

Taking into account all measurements from 28.05. to 06/18/2018. It can be clearly seen that the samples under code 3 (P-Rock Morocco) showed the lowest value on average. This result is due to the availability of nutrients, given the fact that P-Rock Marroko is essentially crude phosphate and that phosphorus is in the form of tri-calcium phosphate, whose mobilization in this form is very slow. Chlorophyll content in the highest percentage was shown by samples under treatment 2 (manure), which is definitely influenced by the nitrogen content as one of the main macroelements.

Table 5:-Display of average value of chlorophyll content in leaves (heavy soil)

\begin{tabular}{|c|c|c|c|c|c|c|}
\hline Treatment (heavy soil) & Label & \multicolumn{5}{|c|}{ Measurement date } \\
\hline & & 28.05 .2018 & 04.06 .2018 & 07.06 .2018 & 11.06 .2018 & 18.06 .2018 \\
\hline Control & 1 & 414.5 & 323.75 & 402.5 & 442.75 & 355.25 \\
\hline Manure & 2 & 531.5 & 529.75 & 572.25 & 474.75 & 582 \\
\hline P-Rock Marroko & 5 & 451.5 & 373 & 381 & 452.5 & 411.75 \\
\hline Dolophos & 8 & 432.5 & 298.75 & 382.75 & 446.25 & 375.75 \\
\hline Berliner Pflanze & 9 & 517.5 & 409 & 533.25 & 461.5 & 455.25 \\
\hline
\end{tabular}

The lowest average value of leaf chlorophyll content in heavy soil was shown by the leaves of the samples under treatment 8 (Dolophos). The value is not surprising, given that the fertilizer in its composition does not have N. The reason why P-Rock Morocco did not show the lowest value in this case is the soil type. Crude phosphates have a particularly favorable effect on heavier soils. The highest values, that is, the chlorophyll content during the measurements, as well as in light soil samples, were shown by the leaves of wheat plants where manure was applied. A slightly lower value, but still showing sufficient content, without manifestation of less leaf color, less development and exuberance of plants, showed treatment under the mark 9 (Berliner Pflanze).

Total grain and straw yields

Table 6:-Total grain and straw yield on light soil

\begin{tabular}{|l|l|l|l|}
\hline Treatment (light soil) & Total weight of grains $(\mathrm{g})$ & Total number of grains & Total straw weight $(\mathrm{g})$ \\
\hline Control & 30,66381398 & 886 & 38,26 \\
\hline Manure & 69,2261248 & 2359 & 77,02 \\
\hline P Rock Marroko & 36,59946074 & 807 & 42,29 \\
\hline Dolophos & 31,300418 & 893 & 39,99 \\
\hline Berliner Pflanze & 52,932898 & 1502 & 60,28 \\
\hline
\end{tabular}


Based on the spreadsheet data on light soil, the lowest total grain and straw yields were recorded on the control (30.66 and 38.26 gr) while the highest total grain and wheat yield was on the Berliner Pflanze treatments (52.93 and $60.28 \mathrm{gr})$.

Table 7:-Total grain and straw yield on heavy soil

\begin{tabular}{|l|l|l|l|}
\hline Treatment (heavy soil) & $\begin{array}{l}\text { Total weight of grains } \\
(\mathrm{g})\end{array}$ & $\begin{array}{l}\text { Total number of } \\
\text { grains }\end{array}$ & Total straw weight (g) \\
\hline Control & 36,41639025 & 946 & 43,08 \\
\hline Manure & 89,3311283 & 2784 & 81,52 \\
\hline P Rock Marroko & 38,30576112 & 1024 & 41,99 \\
\hline Dolophos & 36,9277972 & 978 & 46,68 \\
\hline Berliner Pflanze & 62,5665461 & 1705 & 67,16 \\
\hline
\end{tabular}

On heavy soil, the highest total grain and straw yields were observed with manure treatments (89.33 and 81.52 gr), then with Berliner Pflanze fertilizer (62.56 and 67.16 gr), while the lowest total yield was in control group.

\section{Conclusions:-}

1. For the recovery of phosphorus, innovative and accessible technologies have been developed that allow the separation of phosphorus as a fertilizer from which heavy metals are separated from waste by various processes.

2. Recycled fertilizers according to the Regulation on Organic Agriculture no. Regulation (EC) No 834/2007 fulfills all the criteria to be registered in the list of fertilizers authorized for application.

3. Recycled fertilizers meet all the requirements defined in the Nurec4org project, ie. transparency throughout the production chain, high utilization, safe to use, low energy and resources during production and low emissions and contamination. In addition, the prices of the end product / fertilizer are realistic and acceptable to the producers.

4. Recycled fertilizer, Berliner Pflanze has shown quite good results in wheat production. The rise was most evident in its application. Manure is one of the most common fertilizers used in organic production, and Berliner Pflanze has shown similar results as manure.

5. A big difference was evident in the number of classics and the color of the grain. The plants in the vessels designated as controls and where the treatment of Dolophos, Berliner Pflanze and P-Rock Marroko were used had a color characteristic of the variety, while in the application of manure the color was much darker, and some were green during the harvest period, which is a consequence of prolonged vegetation, as manure also contains a considerable amount of nitrogen in its composition.

6. The use of recycled fertilizers in organic wheat production can increase sustainability, given the fact that they are slow-release nutrients, and their application helps to close the cycle of phosphorus circulation in nature.

\section{Literature:-}

1. Bioland, IASP, Kompetenzzentrum Berlin (2018) „Einsatzmöglichkeiten für Nährstoffrezyklate im Ökolandbau“, Berlin

2. Wollman I., i sar. (2018) „Phosphorus bioavailability of sewage sludge-based recycled fertilizers“, Njemačka str. 158-166.

3. Nättorp A., Remmen K., (2015) »Sustainable sewage sludge management fostering phosphorus recovery and energy efficiency «, Muttenz

4. Ping Q., i sar. (2016) »Characterization of morphology and component of struvite pelets crystallized from sludge dewatering liqour: Effects of total suspended soil and phosphate concentrations « Kina

5. F. Oehl i sar. (2002), ,Phosphorus budget and phosphorus availability in soils under organic and conventional farming“" Nizozemska, str. 25-35

6. N. Khetarpaul i sar. (2008), ,Physico-chemical characteristics, nutrient composition ad consumer acceptability of wheat varieties grown under organic and inorganic farming conditions“ Department of Foods and Nutrition, CCS Haryana Agricultural University, Hisar, India

7. Evans J., Condon J., (2009) „New fertiliser options for managing Phosphorus for organic and low-input farming systems“" Australija, str. 152-162

8. Karlsson I., (2017) „Organic farming increases richness of fungal taxa in the wheat pyllosphere“ Švedska

9. Schitkowsky A., (2015), Berliner Wasserbetriebe“, Berlin 
10. Munir M.T. i sar., (2017) „Phosphate recovery from hidrothermally treated sewage sludge using struvite precipitation" Novi Zeland, str. 171-179

11. Crutchik D., Garrido J.M., (2016) „Kinetics of the reversible reaction of struvite crystallisation“ Department of Chemical Engineering, Institute of Technology, University of Santiago de Compostela, Španije, str. 567-572

12. Kataki S., i sar. (2016) „Phosphorus recovery as struvite: Recent concerns for use o seed, alternative Mg source, nitrogen conservation and fertilizer potential" India and UK, str. 142-156

13. Winker M., i sar. (2009) „Fertiliser products from new sanitation systems: Their poential values and risks“, Njemačka i Švedska

14. Wang X., i sar. (2016) „Influence of lime on struvite formation and nitrogen conservation during food waste composting“, Hong Kong, str. 227-232

15. Witzenberger, Lancashire $(1989,1991)$,Phenological growth stages and BBCH identification keys“

16. Konvalina P., i sar. „Wheat Growing and Quality in Organic Farming“, Češka Republika

17. Lončarić Z. i sar. (2015) »Organska gnojidba i kompostiranje«, Sveučilište Josipa Jurja Strossmayera u Osijeku, Osijek

18. Ohtake H., Tsuneda S. (2019)»Phosphorus Recovery and Recycling«, Japan. 